Dividing Citizens 



\section{DIVIDING CITIZENS}

\section{Gender and Federalism in New Deal Public Policy}

Suzanne Mettler

CORNELL UNIVERSITY PRESS

ITHACA AND LONDON 


\section{Copyright $@$ I 998 by Cornell University}

All rights reserved. Except for brief quotations in a review, this book, or parts thereof, must not be reproduced in any form without permission in writing from the publisher. For information, address Cornell University

Press, Sage House, 5 I 2 East State Street, Ithaca, New York I 485 O.

First published 1998 by Cornell University Press

First printing, Cornell Paperbacks, 1998

Printed in the United States of America

\section{Library of Congress Cataloging-in-Publication Data}

Mettler, Suzanne.

Dividing citizens : gender and federalism in New Deal public policy / Suzanne Mettler.

$$
\text { p. } \mathrm{cm} \text {. }
$$

Includes index.

ISBN 0-8OI4-3329-O (alk. paper). — ISBN o-80r 4-8546-O (pbk. : alk. paper)

I. New Deal, I933-I939. 2. Sex discrimination against womenUnited States-History-2oth century. 3. United States-Politics and government-I933-I945. 4. United States-Social policy. I. Title.

HQI 426.M48 I998

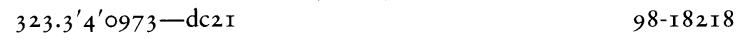

Cornell University Press strives to use environmentally responsible suppliers and materials to the fullest extent possible in the publishing of its books. Such materials include vegetable-based, low-VOC inks and acid-free papers that are recycled, totally chlorine-free, or partly composed of nonwood fibers.

$$
\begin{array}{lllllllllll}
\text { Cloth printing } & \text { IO } & 9 & 8 & 7 & 6 & 5 & 4 & 3 & 2 & \text { I }
\end{array}
$$

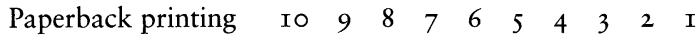


For Wayne 
